\title{
PENDEKATAN ANTROPOLOGI PADA PIIL PESENGGIRI MASYARAKAT ISLAM LAMPUNG PEPADUN
}

\author{
Diah Rizki Nur Kalifah \\ UIN Sunan Kalijaga Yogyakarta \\ 20204081016@student.uin-suka.ac.id \\ Nurul Hidayah \\ UIN Raden Intan Lampung \\ nurul.hidayah@radenintan.ac.id
}

\begin{abstract}
Abstrak
Tujuan dari artikel ini adalah untuk mendeskripsikan pendekatan antropologi pada Piil Pesenggiri terhadap masyarakat Islam beradat suku Lampung Pepadun. Dalam kehidupan sehari-hari salah satu suku masyarakat Lampung pepadun memiliki ciri khas pada aktivitas hariannya seperti penggunaan bahasa sehari-hari yang berdialek $\mathrm{O}$ yang digunakan ketika berinteraksi dengan masyarakat lainnya. Dalam falsafah hidup itu sendiri masyarakat Lampung menyebutnya dengan piil pesenggiri. Penelitian ini menggnakan pendekatan kualitatif dengan jenis penelitian lapangan. Adapun sumber data yang digunakan adalah berdasarkan hasil observasi, wawancara yang dilakukan bersama tokoh adat dan masyarakat adat Lampung Pepadun, dan dokumentasi. Analisis data dalam penelitian ini menggunakan deskriptif kualitatif melalui reduksi data, penyajian data, dan penarikan kesimpulan. Hasil penelitian menunjukkan bahwa dengan menggunakan pendekatan antropologi untuk memahami masyarakat Lampung yang beradat Pepadun pada Piil Pesenggiri maka dapat melihat fenomena yang terjadi pada praktek ajaran Islam, serta dengan pendekatan antropologi tersebut kajian ilmu agamanya dipelajari dengan komprehensif pada kebermaknaan kehidupan beragama di suatu masyarakat itu. Dalam hidup manusia nilai spiritual, nilai sosial, maupun nilai material telah dijabarkan yang dibagi-bagi pada sub-sub tertentu yang ada di Pi'il Pesenggiri menyatakan bahwa Al-Qur'an memberikan contoh sebagaimana perlakuan yang ada di hidup manusia agar melakukan sesuai perintahnya.
\end{abstract}

Kata Kunci: Antropologi; Piil Pesengiri; Pepadun.

\begin{abstract}
The purpose of this article is to describe the anthropological approach to Piil Pesenggiri to the Islamic community of lampung pepadun tribe. In everyday life one of the lampung people has characteristics in their daily activities such as the use of $O$ shirted colloquis used when interacting with other communities. In the philosophy of life itself the people of Lampung call it piil pesenggiri. This research uses a qualitative approach with this type of field research. The data source used is based on observations, interviews conducted with indigenous leaders and indigenous peoples of Lampung Pepadun, and documentation. Data analysis in this study uses qualitative descriptive through data reduction, data presentation, and conclusion withdrawal. The results showed that by using an anthropological approach to understand the people of Lampung who are pepadun in Piil Pesenggiri, it can see the phenomena that occur in the practice of Islamic teachings, and with the anthropological approach the study of religious science is studied comprehensively on the meaning of religious life in a
\end{abstract}


society. In human life spiritual values, social values, and material values have been spelled out that are divided into certain sub-subs in Pi'il Pesenggiri stating that the Qur'an gives examples as well as the treatment that exists in human life in order to perform according to his orders.

Keywords: Anthropology; Piil Pesengiri; Pepadun.

\section{Pendahuluan}

Indonesia memiliki beragam budaya dan perbedaan sosial yang dialami oleh masyarakatnya. Pada tiap-tiap provinsi memiliki suku dan etnik yang berbeda. Salah satu provinsi yang memiliki kelompok ataupun suku di suatu daerah yang terbagi menjadi dua adat kelompok besar adalah provinsi Lampung. Lampung memiliki dua adat masyarakat berkelompok besar yaitu masyarakat Pepadun dan Saibatin. Dua adat tersebut memiliki kekhasan dalam berbahasa sehari-hari maupun aktivitas spiritual pada kajian Islamnya. Masyarakat yang beradat Pepadun dalam keseharian menggunakan bahasa yang berdialek "O" sedangkan masyarakat yang beradat Saibatin cenderung menggunakan bahasa yang berdialek "A". Selain itu masyarakat Lampung memiliki pedoman hidup atau yang biasa disebut sebagai falsafah hidup dengan nama "Piil Pesenggiri" (Yusuf 2013). Dalam Piil Pesenggiri tersebut mengarahkan masyarakat memiliki tujuan pada hidupnya, dimana pada Piil Pesenggiri itu terintegrasi dengan nilai spiritual Islam yang berkaitan pada rukun Islam dan Pancasila (Prakoso 2020). Piil Pesenggiri terbagi menjadi empat yakni juluk adek, nemui nyimah, nengah nyapur, dan sakai sambaian (Nurdiansyah 2016).

Pada ilmu pendidikan mempelajari dan mengenal suatu masyarakat merupakan keharusan karena suatu masyarakat memiliki hal yang unik dan tidak mudah untuk disamakan antara yang satu dan lainnya. Ilmu yang mempelajari kebiasaan maupun tingkah laku manusia adalah ilmu antropologi. Dalam mengamati dan mengkaji mengenai manusia ilmu antropologi memiliki pendekatan yang melatarbelakangi sebuah ilmu tersebut digunakan. Antropologi berasal dari bahasa Yunani yaitu antropos dan logos. Antropos artinya adalah manusia sedangkan logos artinya ilmu (Siregar 2018). Apabila diartikan dan digabungkan maka antropologi merupakan disiplin ilmu dimana menggunakan pendekatan yang berbeda untuk mempelajari perilaku, adat istiadat, kebudayaan, norma, agama, dan hal yang berhubungan terhadap manusia itu sendiri. 
Jika ditelaah lebih lanjut maka masyarakat Lampung seperti masyarakat yang beradat Pepadun memiliki suatu etnik dan perbedaan dalam aktivitasnya sendiri, hal tersebut terlihat dari bahasa yang digunakan pada masyarakatnya. Selain itu, jika dikaji pada sisi ilmu antropologi yang dikaitkan dalam agama maka masyarakat yang beradat Pepadun juga terdapat tindak tanduk yang dilakukan agar masyarakat tersebut bertumbuh dan berkembang. Jika diistilahkan, bahwasannya mengkaji masyarakat dalam kehidupannya sehari-hari dengan pendekatan antropologi yang terintegrasi pada agama, melahirkan sebuah ilmu baru yang disebut sebagai antropologi agama (Umi Rosidah 2011). Biasanya pada suatu masyarakat memiliki kesenjangan atau berjauhan terhadap keseharian yang dilakukan masyarakat itu sendiri dengan nilai ajaran Islam. Sebaiknya pada hal ini diluruskan sebagaimana jika suatu masyarakat bertentangan terhadap nilai ajaran Islam akan membahayakan kehidupan yang dialaminya. Dengan menggunakan pendekatan antropologi untuk memahami masyarakat Lampung yang beradat Pepadun pada Piil Pesenggiri maka dapat melihat fenomena yang terjadi pada praktek ajaran Islam, serta dengan pendekatan antropologi tersebut kajian ilmu agamanya dipelajari dengan komprehensif pada kebermaknaan kehidupan beragama di suatu masyarakat itu. Sehingga makalah ini mengkaji dan menjelaskan tentang pendekatan antropologi pada Piil Pesenggiri masyarakat Lampung Islam yang beradat Pepadun. Penelitian ini menjadi sebuah kebaharuan dan penting untuk di analisis mengenai pendekatan antropologi masyarakat etnik Lampung suku Pepadun dalam kehidupan yang dijalankan dengan berpedoman pada rukun islam yang telah tertuang di Piil Pesenggiri. Sangat penting untuk dikaji dalam aktivitas hidup keseharian suku Pepadun tanpa menghilangkan bahkan mengurangi Piil Pesenggiri yang telah dilaksanakan dan menjadi panutan dalam bertindak sebelum melakukan berbagai hal yang di masyarakat.

\section{Ruang Lingkup Antropologi}

Antropologi berasal dari bahasa Yunani yaitu "anthropos" berarti manusia dan "logos" yaitu berbicara, jadi dapat disimpulkan bahwa antropologi merupakan ilmu yang membahas tentang manusia. Antropologi menurut Kamus Besar Bahasa Indonesia merupakan ilmu yang membahas mengenai awal mula manusia dilahirkan, norma yang berlaku, keyakinan yang dianut, sosial budaya yang diterapkan, dan berbagai hal yang berkaitan dengan manusia itu sendiri (Mahyudi 2016). 
Antropologi diartikan oleh beberapa ahli antara lain: menurut Nur Syam yakni ilmu yang membahas segala segi manusia (Syam 2007). Menurut Yatim Abdullah antropologi adalah berbagai aspek yang mempelajari kehidupan manusia dari segi apapun itu seperti dari warna kulit, warna rambut, kebudayaan, serta keyakinan yang dianut. Menurut Karl Rahner mengemukakan bahwa jika dalam bidang ilmu tertentu membahas ilmu yang mengarahkan pada disiplin ilmunya tetap berlandaskan pada manusia dengan akal pikirannya atau akal budinya. Menurut Ralfh L. Beals dan Harry Hoijen mengatakan bahwa sebuah disiplin ilmu tentang sesuatu hal yang dikerjakan oleh manusia dan hubungannya pada manusia itu sendiri (Febrianti 2020).

Jadi secara garis besar definisi antropologi merupakan disiplin ilmu yang pada intinya mempelajari manusia dimulai dari awal mula manusia dilahirkan, kegiatan yang dikerjakan, tradisi yang dilakukan, kebudayaan yang dilestarikan maupun dilaksanakan, keberagaman bentuk wajah, fisik, sifat dan tingkah laku manusia dimana setiap manusia yang dilahirkan memiliki karakteristik serta berbeda-beda antara manusia yang satu dan manusia yang lain.

\section{Antropologi Dalam Pendidikan Islam}

Mengintegrasikan studi antropologi pada kajian pendidikan Islam merupakan hal yang tidak mungkin. Tidak lain dan tidak bukan untuk meninggikan derajat pendidikan Islam mulai dari Perguruan Tinggi sampai pada madrasah. Selain itu tidak pula dalam memperdaya untuk jual beli terhadap pendidikan Islam agar memasarkan pada masyarakat luas. Jadi studi agama memang sebaiknya termaktub pada disiplin ilmu secara universal, sebagaimana fungsi agama Islam yakni rahmatanlil'alamiin yang artinya rahmat bagi seluruh alam semesta ini) (Riyadi 2019).

Sebagai wahyu Allah SWT agama merupakan sesuatu hal yang dapat mengatur antara hambluminallah, habluminnaanas, ataupun pada manusia sendiri, maupun terhadap lingkungan sosial dan budaya secara umum. Sesuatu hal yang memiliki aturan, prinsip dasar maupun nilai secara global yang dinamakan dengan "syari'at". Sebagai pedoman tingkah laku secara spiritual, moralitas, dan akidah akhlak serta menjadi ilmu teologi maupun ilmu teori yang tertinggi adalah kitab al-Qur'an. Wahyu Allah SWT tidak menghakki suatu ilmu misalnya yang ditemui pada ilmu sekuler (Abdullah 2006). Maksudnya yaitu ilmu pengetahuan itu bersumber pada dua hal yakni pada Allah SWT dan manusia ataupun antara keduanya disatukan sehingga dinamakan teoantroposentris. 
Terdapat lima peristiwa agama menurut Atho Mudzhar dalam mengkaji ilmu terhadap antropologi, antara lain berasal dari sumber dan simbol ajaran agama yang diyakini; dari seorang pemimpin maupun tokoh agama seperti tingkah lakunya maupun konservatif yang menganutnya; menjalankan kewajiban dan sunnahnya seperti shalat, haji, puasa maupun perkawinan dan ahli waris; tempat maupun hal yang dibutuhkan dimana ilmu tersebut didapatkan misalnya masjid, gereja, sajadah, lonceng, dan yang berhubungan dengan hal tersebut; komunitas dimana pengikutnya mengikuti agama tersebut untuk berkumpul misalnya NU, Persis, Syi'ah, dan sebagainya.

Dari lima hal di atas yang menjadi analisis antropologi sehingga berkaitan pada adat istiadat budaya masyarakat yang beragama tersebut. Menurut Amin Abdullah terdapat empat metode kerja antropologi pada ilmu agama, antara lain Mudzhar (1998): memiliki kesamaan pada kalimatnya tidak berpegang teguh pada aturan.; memiliki praktek secara nyata yang ada di masyarakat; memiliki kesamaan antar hubungan pada hal yang dominan di hidup masyarakat secara utuh; membandingan sesuatu hal pada kebiasaan, agama yang dianut, maupun sosial budayanya.

Sedangkan untuk pendidikan Islam tersebut sebagai media penyaluran terhadap agama yang diajarkan, apabila dilihat pada hal yang tidak dapat diperdebatkan yang bertautan pada antropologi. Pendidikan pada bahasa Arab diartikan yaitu tarbiyah, menurut Abdurrahman al-Bani bahwa dalam menjaga seorang anak saat baligh, memiliki kemajuan terhadap potensi yang beraneka ragam, menunjukkan semua fitrah dan kemampuan dalam kebaikan maupun kesempurnaan serta berjalannya suatu proses dengan langkah demi langkah.

Menurut Hasan Langgunung bahwa pendidikan Islam merupakan untuk mempersiapkan penerus bangsa dalam mengisi peranan, meletakkan pengetahuan serta nilai Islam yang disamakan pada manfaat manusia terhadap amal di dunia sehingga dihasilkan diakhirat (Langgulung 1980). Atau bisa diartikan sebagai pergantian antara kemampuan yang diciptakan sampai pada potensi yang diinginkan. Atau biasanya dinamakan sebagai pergantian yang berasal dari kemampuan yang dibawa sampai pada kemampuan yang sempurna. Pendekatan antropologi berperan dalam pendidikan Islam untuk menyikapi peristiwa pada manusia maupun budaya yang berkembang. Jadi membuat ulang konsep untuk mendorong dalam menjawab permasalahan yang terjadi pada saat ini. 
Dalam pendidikan Islam pendekatan antropologi mampu digunakan pada berjalannya kegiatan belajar. Terdapat beberapa dampak yang baik untuk menghasilkan kegiatan belajar, sehingga guru bukan melihat siswa sebagai seseorang yang sama melainkan beranggapan bahwa manusia yang sama karena dalam antropologi jika manusia yang menciptakan adalah Allah SWT dengan bermacam-macam. Jadi guru diwajibkan untuk menanamkan perbedaan pada siswa serta merumuskan tahapan yang akan dilaksanakan sehingga kegiatan pendidikan dapat berjalan.

\section{Pendekatan Antropologi Dalam Kajian Islam}

Dalam ilmu agama pendekatan antropologis menghasilkan antropologi agama yang dinamakan sebagai antropologi budaya bukan antropologi sosial, fisik maupun filsafat. Antropologi agama menurut Wach, A. Mukti Ali dan Kitagawa mengemukakan bahwa agama itu bukan wahyu melainkan sesuatu hal pada yang ada di masyarakat yang dapat disamakan dengan pengetahuan secara agama atau religiusnya. Karakteristik metode antropologi merupakan kelompok manusia yang awalnya sederhana pada kehidupannya yang terdiri dari bidang budayanya. Oleh karena itu, agama yang dikaji bukanlah berdiri sendiri melainkan dikaitkan pada bidang-bidang budaya lain pada kelompok manusia yang berbeda-beda untuk dipelajari. Objek ilmu antropologi pada agama ialah kerangka dari keagamaan tersebut seperti upacara, totem, mite dan lain sebagainya. Beberapa upaya yang dilakukan untuk mempelajari agama untuk melihat secara praktek agama yang berkembang dan tumbuh di suatu masyarakat merupakan makna dari pendekatan antropologi pada mempelajari suatu agama. Dengan pendekatan antropologi maka agama semakin erat kaitannya dengan permasalahan yang dilalui manusia dan berupaya untuk menjabarkan dan membagi suatu jawaban. Terdapat metode yang mampu dilakukan pada studi antropologi untuk mengetahui problem dalam menafsirkan terhadap agama.

Menurut Dawan Rahardjo bahwa antropologi mengedepankan observasi secara nyata atau yang bersifat mengikuti dengan aktif. Dapat disimpulkan bahwa secara khususnya mampu menyetarakan pendekatan secara umum yang dilakukan pada observasi sosiologisnya. Seiring dengan hal tersebut bahwa antropologi agama ditemui keterkaitan antara hal yang baik dengan keyakinan pada agama sesuai keadaan ekonomi dan politik. Sedangkan menurut Karl Max mengemukakan bahwa mengetahui agama 
pada kecanduan masyarakat untuk mendorong mengenalkan permasalahan ataupun perselisihan suatu kelas.

Antropologis dalam kajiannya terdiri dari empat hal, yaitu pertama mempelajari ilmu agama pada beberapa hal yang ada pada pengetahuan untuk melakukan dan mengetahui pengertian agama di suatu masyarakat, lalu mengetahui perkembangan di dalam masyarakat, menurut Taylor mengatakan jika agama merupakan keyakinan pada adanya kekuatan yang supernatural. Kedua terstruktur, Ketiga memiliki fungsi, dan keempat terdapat makna (Ghazali, Gunawan, and Kuswandi 2015).

Antropologi memiliki objek yang terdiri dari memiliki pola pikir yang terdahulu; berinteraksi dengan mite dan symbol; berdasarkan teori dan kenyataan langsung pada agama; melakukan ritual misalnya magic; tingkah laku masyarakat; kebudayaan masyarakat; pemikiran masyarakat (Arifin 2016).

Jika menurut aliran antropologi agama terdapat beberapa aliran, diantaranya pertama menurut Brosnilaw Kacper Malinowski dalam penelitiannya bahwa aliran fungsional maksudnya adalah melihat pemikiran suatu masyarakat secara sederhana terhadap keterkaitan pada aktivitas serta mengutarakan pemikiran mengenai dunia. Kedua menurut Evans Pritchard pada penelitiannya, aliran historis maksudnya membedakan tata urutan masyarakat dan suatu budaya yang beragam. Ketiga menurut Claude Levi Strauss, aliran struktural merupakan bahasa ataupun mite yang melukiskan hubungan dengan alam dan kebudayaan serta kaitannya pada alam dan kebudayaan yang dijumpai melalui hukum cara pandang masyarakat yang dikaji.

Membahas mengenai agama maka mengalami beberapa hambatan pada kajiannya karena mengaitkan keyakinan yang sebenarnya terdapat pada kepercayaan, kebiasaan antropologi dalam menelaah agama, seperti pada abad ke 16 dan 17 dengan perkembangan yang begitu pesat. Menurut Evan-Pitchard bahwa pada adat istiadat antropologi sosial di negara Inggris, permasalahan yang mempelajari mengenai agama ialah pengetahuan kenyataan agama yang bukan sepenuhnya mampu untuk dipahami kecuali jika seseorang tersebut menerapkan agama dengan sendirinya (Suparno 1997). Hambatan dapat terjadi apabila terdapat rasa takut dalam mengatakan problem agama yang sakral atau sensitif untuk dibicarakan dalam mempelajarinya. Hal yang dilakukan menurut kepercayaan agama ialah tidak pembohongan pengetahuan manusia, melainkan 
berawal pada wahyu suci Allah SWT. Jadi kenyataan pada agama yang dipercayai merupakan suatu takdir sosial yang tidak usah dipelajari kembali.

Perlu diketahui jika agama tidak mempengaruhi olah pikir manusia sehingga tidak mampu berkembang secara global ke semua manusia. Pada menyebarkan agama yang berhubungan pada niat manusia dalam memperluas ke suatu tempat-tempat yang lain. Juga bukan niat suatu manusia apabila dalam Islam mampu mengetahui peranan sahabat, menafsirkan serta membangun ajaran agama sehingga menjadi model yang mampu ditiru oleh seseorang manusia. Awal mula beberapa ilmu seperti tafsir, hadits, fikih, usul fikih merupakan hasil dari dibangunnya pengetahuan manusia untuk menafsirkan keyakinan beragama dengan kebutuhan manusia pada lingkungan sosial budayanya. Kemuncullan agama menjadi suatu peristiwa umum yang sederhana pada masyarakat untuk mendorong asal mula kajian mengenai agama tersebut. Ilmu-ilmu mengenai agama yang berkembang tidak hanya karena agama yang tidak bisa dipisahkan pada keadaan sosial, melainkan secara faktanya bahwa agama memiliki peranan yang cukup besar pada perubahan sosial dan peradaban sosial. Menurut Socrate mengemukakan bahwa peristiwa agama merupakan peristiwa mengenai kemanusiaan. Kerap kali menuntaskan permasalahan manusia menggunakan potensi dengan akal pikiran yang sesuai pada kenyataan dan permulaan teknologi. Pada teori simbolisme yang menjadi teori mayoritas pada tahun 70 -an mengambil pada dasarnya yaitu menurut Durkheim, walaupun bukan secara terus terang Durkheim membangun teori mengenai simbolisme. Menurut pemikiran Durkheim tentang simbol dan manfaat ritual di masyarakat yang menjadikan suatu kegiatan dalam menyerahkan keutuhan masyarakat dengan mengilhami para antropolog untuk diimplementasikan dengan pemikiran ritual pada simbol.

Menurut Turner mengetahui bahwa upacara bukan sebagai kewajiban tetapi makna pada yang semestinya dilakukan oleh masyarakat. Penyebab yang menyatakan bahwa pendekatan dalam penelitian di atas menetapkan agama sebagai kenyataan yang tersusun yang bisa diketahui dan dikaji. Menurut cara berpikir ilmu sosial pertanyaan yang sesuai dalam agama tidak ditempatkan pendapat-pendapat secara teorinya, namun ditempatkan pada agama dapat memerankan pada aktivitas sosial manusa itu. Agama ditempatkan pada model sosial yang tersusun, dimana pada kenyataan sosialnya, tetapi pada hubungannya dengan aktivitas manusia, beberapa hal yang tersusun, meskipun 
sesuatu itu ghaib juga menjadi sesuatu yang penting, yang menjadi pusat dari penelitian sosial tersebut. Apabila agama digunakan dalam kepentingan manusia, jadi sebenarnya permasalahan pada manusia merupakan permasalahan dalam agama. Jika di agama Islam manusia dilukiskan menjadi khalifah Allah SWT di muka bumi ini. Secara antropologis bahwa sebenarnya kenyataan manusia ialah kenyataan Allah SWT. Tidak dipelajari secara kenyataan bahwa manusia merupakan kenyataan sosial budaya dan pemaknaan pada ketuhanan tidak akan sempurna, karena sebagian dari kenyataan pada ketuhanan yang tidak dipahami. Dapat terlihat bahwa penelitian mengenai manusia yang berfokus pada antropologi adalah hal yang penting. Dalam membahas kenyataan manusia terpapar dari penyampaian pada al-Qur'an saat mengutarakan pada konsep keagamaan. Seperti dalam menjabarkan mengenai konsep taqwa, al-Qur'an memilih pada konsep "muttaqien" dalam menjabarkan konsep sabar, al-Qur'an melakukan kata “orang sabar" dan sebagainya. Apabila menunjuk pada hal yang disampaikan Qur'an yang demikian sebenarnya, konsep keagamaan tersebut termanifestasikan pada tingkah laku manusia. Jadi dalam pembelajaran konsep agama ditempatkan pada pengertian yang nyata dengan kemanusiaan.

\section{Dalil-Dalil Al-Qur'an Yang Berkaitan Dengan Pendekatan Antropologi}

Mempelajari Islam dalam melakukan berbagai pendekatan maupun metode pada disiplin ilmu merupakan harus dilaksanakan sebab Islam dengan segala sumber ajaran pokok yang termaktub pada al-Qur'an dan sunnah yang tidak hanya membahas persoalan akhlak, ibadah, kehidupan akhirat, tetapi membahas mengenai teknologi, sejarah, ilmu pengetahuan, sosial, ekonomi, pendidikan, politi, dan sebagainya. Pendekatan antropologis pada kajian agama menghasilkan antropologi agama yang diasumsikan beberapa dari antropologi budaya. Berikut ini dalil-dalil yang berhubungan dengan pendekatan antropologi, yaitu Surat Ath-Thoriq ayat 5-7 "Maka hendaklah manusia memperhatikan dari Apakah Dia diciptakan? Dia diciptakan dari air yang dipancarkan, yang keluar dari antara tulang sulbi laki-laki dan tulang dada perempuan." Surat Ar-Ruum ayat 20 "Dan di antara tanda-tanda kekuasaan-Nya ialah Dia menciptakan kamu dari tanah, kemudian tiba-tiba kamu (menjadi) manusia yang berkembang biak." 
Allah menghadirkan surat di atas sebagaimana memberi peringatan yang lalai dan salah mengenai dimana manusia itu berasal, manusia diciptakan dari apa, tujuan dari diciptakannya manusia itu sendiri, yang menciptakan manusia beserta tanggung jawab yang seharusnya dilaksanakan oleh manusia. Dari ayat di atas bahwa sebagai manusia yang dibuat dari air mani yang sangat hina dan dibawanya kotoran pada perut serta badan yang jika suatu ketika akan menjadi bangkai sehingga membuat jijik. Apapun alasannya bahwa manusia tidak diperkenankan memiliki tingkah laku yang sombong kepada sesamanya, sebab Allah SWT menganggap bahwa semuanya memiliki persamaan dalam hal apapun itu sehingga tidaklah pantas bagi manusia untuk angkuh terlebih kepada Allah SWT yang menciptakannya. Manusia ini memiliki perbedaan dalam rupa, fisik, kemampuan namun tetap sebagai manusia sebaiknya menerima daripada perbedaan tersebut di hadapan Sang Pencipta. Manusia yang diartikan sebagai al-Insan merupakan manusia yang memiliki kemampuan yang sangat bodoh terdapat kesalahan, dosa, lupa dan sangat hina sehingga tidak ada daya dan upaya yang dapat dibanggakan ataupun dilebih-lebihkan. Apabila terdapat kesalahan, lupa, dan hal yang kurang baik maka jalan yang dilakukan ialah saling mengingatkan antar sesama serta janganlah menyalahkan antar manusia yang satu dengan manusia yang lain.

Sehebat-hebatnya manusia, maka yang perlu disadari ialah manusia itu berasal dari tanah yang suatu saat akan kembali ke tanah lagi. Tanah ialah hal yang terdapat di bagian bawah yang berarti suatu kerendahan, yang sangat hina. Hikmah yang dapat diambil dari ayat yang telah dijelaskan di atas ialah manusia tidak pantas menganggap manusia lain sangat rendah karena manusia itu sendiri sejatinya memiliki persamaan yaitu berasal dari tanah juga dan akan kembali ke tanah lagi. Yang berkuasa di dunia ini hanya Allah SWT yang sudah menciptakan makhluknya dan seluruh dunia beserta isinya.

\section{Asal Usul Masyarakat Adat Lampung Pepadun}

Lampung memiliki masyarakat yang dibagi menjadi dua kelompok besar yakni pepadun dan saibatin. Warga Pepadun ialah suku yang menempati suatu wilayah di Lampung seperti Lampung Tengah, Lampung Utara, Tulang Bawang dan tempat yang terpencil, jika warga Saibatin biasanya mendiami wilayah pinggiran pantai atau pesisir. Warga Lampung Saibatin bertempat tinggal di Labuhan Maringgai, Pugung, Jabung, Way Jepara, Kalianda, Raja Basa, Teluk Betung, Padang Cermin, Cukuh Balak, Way 
Lima, Talang Padang, Kota Agung, Semaka, Suoh, Sekincau, Batu Brak, Belalau, Liwa, Pesisir Krui, Ranau, Martapura, Muara Dua, Kayu Agung, serta empat kota yang berada di Sumatera Selatan, Cikoneng di Pantai Banten dan Merpas di Selatan Bengkulu. Warga beradat Saibatin biasa dinamakan Lampung Pesisir sebab secara keseluruhan bertempat tinggal di bagian pantai timur, selatan dan barat Lampung yang terbagi menjadi Paksi Pak Sekala Brak (Lampung Barat), Lampung Timur, Keratuan Darah Putih, Keratuan Semaka, Keratuan Komering, dan Cikoneng Pak Pekon (Irham 2013).

Menurut kitab Kuntara Raja Niti bahwa warga Lampung seperti Pubian, Pesisir, Abung dan sebagainya yang asal muasal dari pagaruyung keturunan Putri yang turun dari langit kemudian Kuala Tungkal, terdekat dengan berdiam di Skala Brak, jadi cucunya Umpu Serunting (Sidenting) menurunkan anak laki-laki yang berjumlah lima orang yakni Indra Gajah, Belenguh, Pa'lang, Panan, dan Sangkan. Berdasarkan cerita yang dipaparkan bahwa warga Lampung yang berasal pada suatu wilayah Skala Brak dimana tempat tersebut ialah suatu pedesaan yang berisi orang Lampung. Kemashuran Skala Brak di dapatkan dari perkataan secara terus menerus pada wewarahan, tambo dan dalung, jika seseorang bertanya pada salah seorang masyarakatnya mengenai asal mula mereka dari mana kemudian orang tersebut memberikan jawaban dari bukit serta akan memberitahu ke tempat yang berdanau besar.

Jadi sampai pada saat ini historis Lampung dilapisi oleh ketabuan sebab terbatasnya data dan berbagai informasi historis yang sangat akurat serta kurangnya mencari historis yang dilaksanakan oleh beberapa ahli sejarah. Pada sejarahnya rentetan Skala Brak yang berawal ditempati oleh suku Tumi pada saat itu masih menganut aliran animisme. Suku bangsa itu mengagungkan pada tumbuhan dengan nama lemasa kepampang yakni tumbuhan nangka yang memiliki cabang dua. Dimana cabang pertama yaitu nangka dan satunya berjenis tumbuhan yang memiliki getah. Hal yang berbeda lemasa kepampang dari cerita rakyat yang diceritakan ialah jika tersentuh getah pada cabang kayu sebukau maka menyebabkan suatu penyakit koreng atau kulit yg lain, sehingga pengobatannya harus menggunakan getah yang berasal dari cabang lainnya. Kemudian kayu lemasa kepampang dijadikan untuk tumbuhan yang dikeramatkan. Lalu masuknya Islam penyebarannya dilakukan oleh putra raja yang berjumlah empat orang yakni Umpu Berjalan di Way, Umpu Belunguh, Umpu Nyerupa, serta Umpu Peranong, dengan diberikan pada seorang penduduk dengan nama Bulan, mereka membuat suatu 
persatuan yang dinamakan Paksi Pak yang berjumlah empat saudara, yang awal mula Paksi Pak, dimana diucapkan pada sebuah naskah kuno yang dinamakan Kuntara Raja Niti (Kitab Hukum Adat). Namun, pada persi karya yang diceritakan bahwa nama mereka ialah Inder Gajah, Paklang, Sikin, Belunguh, serta Indrawati. Pada keempat Umpu kemudian diberikan kepada agama Islam dan berteman pada Puteri Bulan.

Suku Tumi tersebut mampu mengalahkan dan tumbuhan lemasa kepampang dipangkas serta dibuat menjadi Pepadun, maka dari situlah bahwa aliran animisme hilang sedikit demi sedikit dari tanah Skala Brak sampai saat ini suku Lampung ialah kebanyakan mengikut agama Islam. Warga adat Pepadun memiliki dua simbolik yakni bermakna menyatukan pengesahan atau mengadukan dengan mentasbihkan apabila seseorang yang duduk di atas tersebut ialah seorang raja serta bermakna tempat untuk mengadukan berbagai hal serta mengambil keputusan pada mereka yang sudah menempatinya. Manfaatnya boleh digunakan pada raja yang menduduki di Skala Brak saat itu. Pepadun diabadikan sebagai beberapa nama tradisi Lampung yakni adat Lampung Pepadun yang kekal sampai saat ini. Pepadun mempunyai pengertian ialah menduduki yang terdapat dilakukan atau menempati pada pengangkatan beberapa raja adat, mentasbihkan apabila seseorang yang menempati di atasnya ialah seorang raja. Menurut Hilman Hadikusuma mengemukakan bahwa warga Lampung yang beradat Pepadun ialah suatu kelompok yang memiliki ritual dalam pengangkatan beberapa raja dengan menggunakan alat pada ritual yang merupakan tempat dalam suatu adat yang diperlakukan saat ritual untuk mengambil gelar yang disebut dengan upacara Cakak Pepadun.

Pada semestinya bahwa warga yang beradat Pepadun mengikuti prinsip pada keturunan ayah yaitu patrilineal, yaitu seorang laki-laki tertua memegang pada kekuasaan adat. Pada anak laki-laki tertua yang berasal dari anak yang mewarisi kepimpinan ayah sebagai kepala keluarga. Pada hal tersebut mencerminkan tatanan dan wajah dari perkawinan adat dan ritual-ritual adat yang terjadi. Penempatan penyimbang begitu dihormati dan keistimewaan sebab fokus pada pemerintahan yang terdekat, baik yang berawal dari satu keturunan yang berhubungan darah, satu hubungan adat maupun sebab perkawinan (Zaini, Yanzi, and Nurmalisa 2018).

\section{Konsep Masyarakat Adat Lampung Pepadun}


Beberapa warga yang terdapat di negara Indonesia ialah warga Lampung, warga Lampung terdiri dari dua yakni, warga beradat Pepadun dan warga yang beradat Saibatin. Warga beradat Pepadun terbagi pada perserikatan adat yaitu pertama, Abung Siwow Migow yang berada di sekeliling Way Abung, Way Rarem, Way Terusan, Way Pangubuwan, dan Way Seputih. Kedua, Tulang Bawang Megow Pak yang berada di sekeliling Way Tulang Bawang Ilir. Ketiga, Way Kanan Buway Lima yang berada di sekeliling Way Kanan (Tulang Bawang Ulu, Way Umpu dan Way Besai) dan Way Sungkai. Keempat, Pubian Telu Suku berada di sekeliling Way Sekampung Tebag dan Way Sekampung Ulu (Syarifah, Syah, and Arif 2017).

Secara global warga yang beradat tersebut mengikuti adat yang asasnya sama untuk menjaga tatanan kedekatan patrilineal dan wujud perkawinan adat serta ritual adat Pepadun yang dilakukan atas dasar musyawarah dan mufakat prowatin adat dimana seorang anak lelaki tertua beserta keturunannya tertua menduduki kekuasaan adat. Manusia secara alamiah memiliki naluri sosial yang meyakini tak biasa untuk berdiri sendiri serta mengasingkan diri sehingga tidak memiliki teman, baik itu pada aktivitas keseharian maupun menjaga kehidupan pada upaya pemenuhan keinginan hidupnya. Tempat dimana seseorang untuk hidup secara berbarengan dengan terikat serta menjalin hubungan interaksi sehingga komunikasi sosial dan berorganisasi inilah ciri manusial yang wajar dan sesuai pada kodratnya. Tempat bertemu dari satu orang ke orang yang lain disebut sebagai warga atau perkumpulan kehidupan. W.J.S Poerwadarminta mengemukakan bahwa warga sebagai perkumpulan kehidupan beberapa manusia maupun sehimpun beberapa yang hidup secara berbarengan pada hal dengan wadah pada hubungan dengan norma tertentu. Selo Soemardjan mengemukakan bahwa masyarakat ialah beberapa orang yang hidupnya dilakukan secara bersama yang membuahkan kebiasaan yang telah diwariskan oleh nenek moyang. Berdasarkan pengertian masyarakat di atas maka warga ialah sekelompok manusia yang berkomunikasi serta mempunyai beberapa hubungan yang kuat sebab mempunyai permasalahan yang hampir sama, memiliki hubungan batin yang hampir sama pada mereka dan tatacara dengan kebijakan dan musyawarah pada beberapa komunitas lalu memiliki ikatan yang saling berkaitan pada mereka. Warga adat merupakan warga pribumi yang menempati daerah tersebut. Masyarakat adat seperti yang dikemukakan oleh Aman (Aliansi Mayarakat Adat Nusantara) di Kongres I tahun 1999 adalah 
kelompok yang menyala berlandaskan awal mula nenek moyang secara terus menerus di atas daerah adat yang mempunyai kedaulatan di atas tanah serta kekayaan alam, aktivitas sosial budaya yang diatur pada norma adat serta suatu lembaga adat yang mengelola aktivitas yang berlangsung pada masyarakatnya.

Menurut istilah Pepadun yaitu berasal dari Pepadun-an artinya para petinggi suatu kerajaan atau permusyawaratan untuk melakukan keadilan di suatu adat dengan didatangi oleh tokoh adat sekitar. Pepadun ialah kedudukan kepunyimbangan yang terdiri dari bahan kayu dengan memiliki kaki emapt serta terdapat ukir-ukirannya. Kedudukan yang didapatkan oleh punyimbang terlebih dahulu kemudian ke seba lalu Banten pada abad 17. Pada pendapat di atas menyatakan Pepadun ialah tempat untuk dilakukannya sebagai singgah sana punyimbang ketika bermusyawarah pada saat diadakan peradilan adat, sebab punyimbang ialah seseorang yang memiliki pangkat tertinggi serta musti dihormati lalu yang menempatinya di bawah setelahnya ialah beberapa sunan, pengiran, serta saudara terdekat, adat yang lain dan bukan saudara yang dekat maka tidak diperkenankan untuk ikut pada sidang peradilan adat (Maretha, Imron, and Ekwandari 2019).

\section{Pi'il Pesenggiri}

Identitas pada warga Lampung yang menjadi falsafah atau pedoman bagi masyarakat Lampung disebut Pi'il Pesenggiri. Pada prinsip-prinsip yang terjadi bahwa Pi'il Pesenggiri ialah sebuah prinsip yang menginginkan untuk sejajar di kehidupan pada siapapun. Kesamaan diartikan sebagai suatu masyarakat yang hidupnya tidak di atas apabila yang lainnya berada di bawah begitupun sebaliknya jika melihat yang tidak senang untuk hidup di bawah apabila yang lain berada di atas. Pi'il Pesenggiri ialah berbagai hal yang berkaitan harga diri, tingkah laku serta perilaku mempertahankan dan menegakkan harkat dan martabat dengan pribadi ataupun kelompok yang mampu dijaga. Pi'il Pesenggiri ialah sistem nilai dan petunjuk dalam bertingkah laku yang dilakukan oleh masyarakat Lampung untuk kehidupannya sehari-hari. Dapat dipaparkan bahwa Pi'il Pesenggiri merupakan warisan nenek moyang yang dijadikan sebagai kepribadian, identitas, petunjuk dalam berperilaku masyarakat yang bertempat tinggal di daerah Lampung (Yusuf 2013). Di bawah ini dijabarkan yang terdapat di Pi'il Pesenggiri yaitu:

\section{Bejuluk Beadek/Khopkhama Delom Bekekhja}


Secara istilah Bejuluk Beadek/Khopkhama Delom Bekekhja berasal dari Juluk dan Adek Bejuluk yang berarti memiliki nama serta Adek berarti memiliki gelar. Arti yang terkandung ini yakni mengharuskan perjuangan dalam peningkatan untuk kesempurnaan hidup, sopan santun, aturan dengan benar. Dilihat dari pengertian yang asli bahwa identitas warga Lampung yang dapat dipertanggungjawabkan baik itu lahir maupun batin, material serta spiritual. Pada tiap orang bahwa mempunyai Juluk dan Adek mengharuskan bermoral tinggi serta menjadi panutan untuk warga yang berada di sekelilingnya. Tahapan pada adat yang ada pada adat Lampung Pepadun dari yang tinggi hingga yang ke rendah antara lain: Stan/ Suttan, Tuan/Khaja, Minak/Batin, Ngedikou/Khadin, Pengiran/Minak, Rajou/Kemas, Ratu/Mas

Pada tahapan bejuluk beadek mempunyai tempat sendri mulai dari yang tinggi sampai rendah. Isi dari nilai yang ada di bejuluk beadek tentunya sangat sesuai dengan ajaran yang dianut agama Islam, seperti ada pada surat Ar-Rad ayat 11 berikut. "Bagi manusia ada malaikat-malaikat yang selalu mengikutinya bergiliran, di muka dan di belakangnya, mereka menjaganya atas perintah Allah. Sesungguhnya Allah tidak merobah Keadaan sesuatu kaum sehingga mereka merobah keadaan yang ada pada diri mereka sendiri. dan apabila Allah menghendaki keburukan terhadap sesuatu kaum, Maka tak ada yang dapat menolaknya; dan sekali-kali tak ada pelindung bagi mereka selain Dia."

Pada ayat tersebut keterhubungan Bejuluk Beadek ialah mengenai penjelasan jati diri seseorang yang sedang berjuang menumbuhkan kualitas kehidupannya. Apabila orang tersebut mempunyai adek (gelar) atau jati diriharus memperjuangkan dengan setara agar menjaga serta menumbuhkan kualitasnya kehidupan dari bebagai aspek. Adapun nilai yang dilakukan yaitu nilai ketauhidan, nilai spiritual, nilai akhlak, serta nilai pengetahuan serta nilai yang terbarukan dengan nyata pada aktivitas manusia tersebut. Dengan begitu apabila seseorang memiliki adek (gelar) akan dihormati dan memiliki keyakinan dari masyarakat, serta yang utama ialah maka mendapatkan ridha Allah SWT, jika gelar yang didapatkan mampu dipertahankan kehormatan yang ada pada dirinya sehingga berkelakuan baik, serta menjadi tauladan untuk masyarakat sekelilingya.

\section{Nemui Nyimah/Bepudak Waya}


Nemui Nyimah adalah unsur selanjutnya yang terdapat di Pi'il Pesenggiri, arti dari nemui nyimah terbagi menjadi dua yaitu Nemui yang berarti menerima tamu sedangkan Nyimah yang berarti mendapatkan berbagai tanpa imbalan, atau dikatakan royal. Maksud daripada Nemui Nyimah ialah keharusan memberlakukan hormat dan sopan pada seluruh anggota masyarakat, bantu membantu serta menghargai para tamu. Dilihat dari berbagai sudut pandang sosial logis,Nemui Nyimah merupakan sesuatu tingkah laku yang berkumpul di kehidupan kemungkinan orang Lampung dapat beradaptasi pada masyarakat lain di sekelilingnya. Isi dari nilai yang ada di Nemui Nyimah sesuai dengan ajaran yang dianut oleh agama Islam di surat An-Nisa ayat 1 berikut.

"Hai sekalian manusia, bertakwalah kepada Tuhan-mu yang telah menciptakan kamu dari seorang diri, dan dari padanya Allah menciptakan isterinya; dan dari pada keduanya Allah memperkembang biakkan laki-laki dan perempuan yang banyak. dan bertakwalah kepada Allah yang dengan (mempergunakan) nama-Nya kamu saling meminta satu sama lain, dan (peliharalah) hubungan silaturrahim. Sesungguhnya Allah selalu menjaga dan mengawasi kamu."

Dijelaskan pada ayat di atas apabila menjalin persaudaraan sangat utama dibandingkan dengan melakukan perbuatan yang lain. Manfaat daripada menjalin persaudaraan atau silahturahmi yaitu dilapangankan rezeki dan diberikan umur yang panjang; diberi Ridho Allah SWT; didekati oleh sesame; menanamkan rasa cinta kasih kepada sesama, menumbuhkan rasa kebersamaan dan kekeluargaan; mempererat dan memperkokoh jalinan persaudaraan dijauhkannya dari kesusahan dalam pertolongan; memberikan pahala setelah kematian sebab kebaikan dari menjalin persaudaraan diingat selalu sampai orang yang terjalin persaudaraan mendoakannya; menjadikan setan dan iblis murka sebab saling menjaga antar sesama.

Pada Nemui Nyimah berisi nilai kebersamaan dan kesamaan, sehingga melahirkan kedekatan dan kerukunan dengan berlandaskan pada nilai spiritual terhadap berbagai hal yang disampaikan pada kewajiban untuk menjalin persaudaraan. Jadi makna daripada unsur budaya Nemui Nyimah yaitu sebaiknya mengimplementasikan dan menjaga nilai yang terdapat pada budaya Nemui Nyimah sebab manusia adalah makhluk sosial yang memerlukan bantuan orang lain.

\section{Nenggah Nyappur/Tetangah-Tetanggah}


Warga Lampung beradat Pepadun terbagi menjadi dua antara lain Nengah dan Nyappur. Makna dari Nengah diambil dari kata tengah yang jika diartikan terletak di tengah sedangkan Nyappur merupakan berbaur atau beradaptasi. Jika digabungkan kedua kata tersebut ialah perilaku yang pandai untuk berkumpul dan bersahabat serta menghargai. Pada aktivitas yang terjadi di lingkungan sekeliling sikap terbuka dan ramah terhadap suatu komunitas. Maksud dari Nengah Nyappur adalah mewajibkan agar berkumpul di antara masyarakat dengan mengungkapkan pendapat yang tertuang dalam musyawarah untuk mufakat. Nengah Nyappur memiliki makna yaitu memperbaiki persoalan luas yang ada dimasyarakat. Jadi manusia itu sebaiknya mempunyai potensi agar memiliki standar yang tinggu pada bidang spiritual maupun material, ataupun intektual dan moral (Syahputra 2020).

Nilai yang terkandung pada Nengah Nyappur diterangkap dalam surat AlHujarat ayat 13 berikut. "Hai manusia, Sesungguhnya Kami menciptakan kamu dari seorang laki-laki dan seorang perempuan dan menjadikan kamu berbangsa - bangsa dan bersuku-suku supaya kamu saling kenal-mengenal. Sesungguhnya orang yang paling mulia diantara kamu disisi Allah ialah orang yang paling taqwa diantara kamu. Sesungguhnya Allah Maha mengetahui lagi Maha Mengenal."

Dijelaskan pada surat di atas bahwa mewajibkan untuk berkumpul bersama, karena Allah SWT menciptakan manusia yang beragam agar diantaranya saling mengenal. Dengan keberagaman tersebut mampu menyatukan perbedaan yang terjadi di masyarakat. Nilai yang terkandung pada Nengah Nyappur ialah inteletualitas, sosialitas, moralitas, solidaritas, yang didukung dengan kesadaran religius dan spiritual. Pada Nengah Nyappur nilai kehidupan yang ada di dalamnya berupa nilai sosial yang bertautan pada prinsip kebersamaan, nilai moralitas yang menumbuhkan kehangatan atau harmonis, nilai solidaritas yang didukung pada ke eksistensi serta yang terakhir adalah nilai religius-spiritual yang berkenaan pada dukungan hati yang berdasar pada kehendak Allah SWT.

\section{Sakai Sambayan/Khepot Delon Mufakat}

Sakai Sambaian ialah unsur daripada Piil Pesenggiri. Sakai yang diartikan sebagai pemberian terhadap hal untuk seseorang maupun komunitas berupa barang maupun jasa, namun menginginkan imbalan. Sedangkan Sambayan adalah pemberian terhadap beberapa hal untuk seseorang maupun komunitas berupa barang dan jasa 
dengan tidak menginginkan timbal balik atau imbalan. Jadi dapat dimaknai bahwa Sakai Sambayan merupakan perilaku yang suka membantu karena berlandaskan kebersamaan dengan saudara maupun orang atau warga lain yang ada di lingkungan sekitar. Kandungan yang termaktub pada Sakai Sambaian ialah memiliki jiwa sosial, bergotong royong dalam hal kebaikan terhadap sesama dengan menginginkan imbalan atau sebaliknya. Menurut warga Lampung Sakai Sambayan menempati prinsip pada pedoman warga Lampung di suatu kegiatan kemasyarakatan serta memiliki fungsi Sakai Sambayan pada warga Lampung yang bermanfaat untuk memunculkan konsep keadilan sosial yang benar dan bersumber dari kegiatan masyarakat sebagai sosialisasi bersamasama agar mengantisipasi persoalan antar suku, agama, ras, dan sebagainya (Syukur 2002). Pada ajaran Islam Sakai Sambayan diterangkangkan pada surat Al-Maidah ayat 2 berikut. "Hai orang-orang yang beriman, janganlah kamu melanggar syi'ar-syi'ar Allah, dan jangan melanggar kehormatan bulan-bulan haram, jangan (mengganggu) binatang-binatang had-ya, dan binatang-binatang qalaa-id, dan jangan (pula) mengganggu orang-orang yang mengunjungi Baitullah sedang mereka mencari kurnia dan keredhaan dari Tuhannya dan apabila kamu telah menyelesaikan ibadah haji, Maka bolehlah berburu. dan janganlah sekali-kali kebencian(mu) kepada sesuatu kaum karena mereka menghalang-halangi kamu dari Masjidilharam, mendorongmu berbuat aniaya (kepada mereka). dan tolong-menolonglah kamu dalam (mengerjakan) kebajikan dan takwa, dan jangan tolong-menolong dalam berbuat dosa dan pelanggaran. dan bertakwalah kamu kepada Allah, Sesungguhnya Allah Amat berat siksa-Nya."

Pada ayat di atas bahwa Sang Pencipta mengajak manusia untu membantu dalam hal kebaikan dengan beriringan dengan ketakwaan kepada Allah SWT. Karena pada ketakwaan tersebut ada ridho Allah, dan jika berbuat baik itu banyak disenangi oleh orang lain. Jadi ridho yang Allah berikan dan Ridho manusia sebenarnya kebahagiaan yang sempurna dan nikat bagi yang mendapatkannya. Pada Sakai Sambaian termaktub nilai moralitas atau akhlak yang karimah, semua nilai hidup yang menjadi tujuan manusia itu hidup, nilai individualisme dan sosial, nilai material dan intelektual. Sakai Sambaian merupakan perilaku saling membantu agar memiliki ikatan yang baik diantara manusia satu dengan manusia lainnya agar tertimbulnya ikatan baik tersebut maka 
manusia wajib memiliki sikap saling membantu pada hal kebaikan maupun ketakwaan pada Allah SWT.

\section{Konsep Kebudayaan Pi'il Pesenggiri Dalam Antropologi}

Pada falsafah hidup orang Lampung di setiap tingkah laku yang dilakukan mereka menggunakan pedoman yang biasa dipakai oleh masyarakat tersebut secara turun temurun yang disebut Pi'il Pesenggiri. Pi'il Pesenggiri merupakan acuan masyarakat Lampung dalam berprinsip sebagai manusia yang beradab, seiring pada perkembangan zaman yang berlalu Pi'il Pesenggiri tetap dilaksanakan oleh masyarakat Lampung. Masyarakat Lampung yang menggunakan pedoman dikehidupannya adalah masyarakat adat Pepadun dan Saibatin. Dengan Lampung memiliki dua suku yang berbeda maka diimplementasikannya konsep agar satu sama lain tidak terjadi perselisihan baik dalam hal berinteraksi maupun hal yang lainnya yang berpengaruh terhadap kehidupan strata sosialnya.

Pi’il Pesenggiri terbagi menjadi empat kategori, yakni Bejuluk Beadek, Nemui Nyimah, Nengah Nyappur, dan Sakai Sambaian. Pada nilai Bejuluk Beadek maksudnya adalah jika seseorang memiliki gelar yang tinggi maka hal yang dilakukan adalah menjaganya artinya jika memiliki tingkatan yang lebih tinggi jabatan atau hal yang lain maka sikap manusia yang baik adalah sopan santun. Dan apabila seseorang memiliki gelar yang berbeda sebaiknya sikap yang dilakukan sesuai dengan gelar yang didapatkannya.

Pada Nemui Nyimah ini masyarakat Lampung menerima seseorang baik itu tamu atau orang yang baru datang dengan memberikan perlakuan yang baik seperti sopan santun dan menghargainya. Karena dengan melakukan perilaku yang baik pada orang lain akan menjalin silahturahmi. Silahturahmi dapat memupuk persaudaraan, dengan silahturahmi maka manusia yang satu dengan lainnya akan saling menanamkan cinta kasih sayang terhadap sesama dan dari silahturahmi tersebut merupakan sikap yang harus dibudayakan oleh manusia sebagaimana telah diterangkan dalam surat An-Nisa ayat 1 bahwasanya hubungan silahturahmi akan menimbulkan beberapa manfaat serta Allah SWT mewajibkan silahturahmi antar sesama sehingga menjauhkan perangai yang tidak baik yang ada pada setan dan iblis.

Pada unsur yang ketiga adalah Nenggah Nyappur, yaitu berbaur atau berkumpul bersama kepada siapa saja tanpa memandang jabatan, umur, maupun hal-hal 
menjadikan manusia tersebut berbeda. Dengan berkumpul bersama maka terjadilah suatu solidaritas antar manusia yang satu dengan lainnya karena pada prinsipnya manusia tidaklah hidup sendiri melainkan berdampingan dengan manusia yang lain. Untuk menumbuhkan kehangatan dan kebersamaan antar manusia maka dengan cara berbaur atau berkumpul bersama tanpa memandang siapa dan apa dalam diri manusia itu maka mampu menyatukan perbedaan yang berada di suatu masyarakat itu.

Pada unsur yang terakhir adalah Sakai Sambayan, unsur Sakai Sambayan berarti menolong sesama tanpa meminta imbalan atau hal yang biasa disebut sebagai upah. Manusia itu adalah manusia yang memerlukan bantuan orang lain, tanpa manusia lain yang membantu aktivitas sehari-harinya maka manusia tersebut memiliki ketimpangan atau kekurangan yang tidak lengkap dalam menjalankan aktivitasnya sehari-hari. Membantu orang lain adalah suatu kebaikan yang telah diterangkan pada surat AlMaidah ayat 2 bahwa membantu orang lain merupakan suatu kebaikan dan suatu hal yang diridhoi oleh Allah SWT.

\section{Penutup}

Dari penjelasan unsur-unsur falsafah hidup orang Lampung diatas lebih menekankan unsur yang pertama yaitu pada Piil Pesenggiri. Unsur Piil Pesenggiri adalah demi mempertahankan suatu kehormatan diri, maka seseorang harus memiliki harga diri agar mampu hidup sejajar dengan yang lainnya, dimana pemahaman dari harga diri ini ialah rasa malu (piil) terhadap suatu kesalahan, serta harga diri (Pesenggiri) dalam membela kebenaran, bekerja keras, berani dan pantang menyerah dalam membela kebenaran. Seseorang yang memiliki harga diri yang tinggi berarti memiliki kesadaran untuk dapat membangkitkan nilai-nilai positif kehormatan diri sendiri dan orang lain, yaitu sanggup menjalani hidup dengan penuh kesadaran serta tanggung jawab terhadap setiap perbuatan yang dilakukan, sedangkan jika hidup egoisme dan berlebihan dalam mengagungkan kemampuan diri sendiri atau sombong merupakan gambaran tentang rendahnya harga diri atau runtuhnya kehormatan diri untuk itu setiap individu harus memelihara kehormatan diri dari segala hal yang akan merendahkan, merusak dan menjatuhkannya.

\section{Daftar Pustaka}

Abdullah, M. Amin. 2006. "Islamic Studies Di Perguruan Tinggi Perguruan IntegratifInterkonektif." 
Arifin, Tajul. 2016. "Antropologi Hukum Islam.”

Febrianti, Riska. 2020. "Tradisi Pesta Lammang Desa Lantang Kecamatan Polongbangkeng Selatan Kabupaten Takalar (Studi Unsur-Unsur Budaya Islam)."

Ghazali, Dede Ahmad, Heri Gunawan, and Engkus Kuswandi. 2015. "Studi Islam: Suatu Pengantar Dengan Pendekatan Interdisipliner."

Irham, Muhammad Aqil. 2013. "Lembaga Perwatin Dan Kepunyimbangan Dalam Masyarakat Adat Lampung: Analisis Antropologis." Analisis: Jurnal Studi Keislaman 13(1):155-72.

Langgulung, Hasan. 1980. Beberapa Pemikiran Tentang Pendidikan Islam. Alma'arif.

Mahyudi, Dedi. 2016. "Pendekatan Antropologi Dan Sosiologi Dalam Studi Islam." Ihya Al-Arabiyah: Jurnal Pendidikan Bahasa Dan Sastra Arab 2(2).

Maretha, Ria, Ali Imron, and Yustina Sri Ekwandari. 2019. "Intar Padang (Terang) Dalam Sistem Perkawinan Pada Masyarakat Pepadun Marga Suway Umpu Tulang Bawang." PESAGI (Jurnal Pendidikan Dan Penelitian Sejarah) 7(4).

Mudzhar, Atho. 1998. Pendekatan Studi Islam: Dalam Teori Dan Praktek. Pustaka Pelajar.

Nurdiansyah, Arie. 2016. "Nilai-Nilai Pendidikan Islam Berbasis Budaya Lokal Piil Pesenggiri Di Masyarakat Desa Tanjung Agung Lampung Selatan.”

Prakoso, Abimanyu Satrio. 2020. "Nilai-Nilai Komunikasi Islam Dalam Falsafah Hidup Masyarakat Lampung." Alamtara: Jurnal Komunikasi Dan Penyiaran Islam $4(1): 1-17$.

Riyadi, Ivan. 2019. "Manajemen Pendidikan Bermuatan Antropologi, Agama Dan Sosial." Cendekia: Jurnal Kependidikan Dan Kemasyarakatan 17(2):301-16.

umi Rosidah, Feryani. 2011. "Pendekatan Antropologi Dalam Studi Agama." Religio: Jurnal Studi Agama-Agama 1(1):23-32.

Siregar, Mustamar Iqbal. 2018. "Pendekatan Antropologi Dalam Pendidikan Islamuntuk Merawat Kemajemukan.” Aceh Anthropological Journal 2(1):27-53.

Suparno, Paul. 1997. "Filsafat Konstruktivisme Dalam Pendidikan." Yogyakarta: Kanisius 12-16.

Syahputra, Muhammad Candra. 2020. "Nilai-Nilai Pendidikan Karakter Dalam Budaya Nengah Nyappur.” Jurnal PAI Raden Fatah 2(1):1-10.

Syam, Nur. 2007. Madzhab-Madzhab Antropologi. LKIS Pelangi Aksara.

Syarifah, Farisa, Iskandar Syah, and Suparman Arif. 2017. "Kayu Ara Pada Acara Begawi Adat Lampung Pepadun Buay Nyerupa Lampung Tengah.” PESAGI (Jurnal Pendidikan Dan Penelitian Sejarah) 5(5).

Syukur, Abdul. 2002. "Peristiwa Lampung 1989." Buletin Al-Turas 8(1):9-26.

Yusuf, Himyari. 2013a. "Dimensi Epistemologis Filsafat Hidup Piil Pesenggiri Dan Relevansinya Bagi Moralitas Islam." Fakultas Ushuluddin IAIN Raden Intan Lampung. 
Yusuf, Himyari. 2013b. "Filsafat Kebudayaan, Strategi Pengembangan Kebudayaan Berbasis Kearifan Lokal.” Bandar Lampung: Harakindo Publishing.

Zaini, Inten Putri Resmi, Hermi Yanzi, and Yunisca Nurmalisa. 2018. "Peranan Tokoh Adat Terhadap Pelestarian Adat Pengangkonan Pada Masyarakat Lampung Pepadun.” Jurnal Kultur Demokrasi 5(11). 